\title{
Consigned to oblivion: Rehabilitation of First World War disabled veterans in Portugal (1917-1927)
}

\author{
HELENA DA SILVA \\ Instituto de História Contemporânea - Universidade NOVA de Lisboa, Faculdade de \\ Ciências Sociais e Humanas., Lisbon, Portugal
}

The First World War is known for its use of advanced weaponry, which caused massive injuries. Over 8,000 Portuguese soldiers who had fought in the African and European theatres of war returned home with a disability. Through a qualitative analysis of archival data, newspaper articles, and legislation, this article examines what was done for these disabled veterans in Portugal between 1917 and 1927, drawing comparisons with similar situations in other countries. As it will be noted, voluntary organisations and the State took limited measures to rehabilitate disabled ex-servicemen, who were consigned to oblivion.

KEYWORDS Great War, Portugal, maimed soldiers, re-education, disabled war veterans

Private Gaspar lost a thumb due to an accident with his rifle; he was admitted to one of the two rehabilitation institutes in Lisbon, where he carried out a pedagogical and orientation test. He was quickly discharged as he did not need physiotherapy nor reeducation and could continue working as a digger, his occupation before the war. ${ }^{1}$ Although this was a successful case, one might ask if other ex-servicemen who wanted to re-enter civilian life despite their disability faced the same reality. What was done to

\footnotetext{
${ }^{1}$ J. Pontes, Mutilados portugueses, narrativas de guerra e estudos de reeducação (Lisboa: Guimarães e $\mathrm{C}^{\mathrm{a}}$, 1918), 56-8.
} 
help disabled Portuguese veterans reintegrate into society? This article focuses on the measures taken by the State and voluntary organisations to rehabilitate and provide economic support to disabled veterans, drawing comparisons with other countries.

Scholars estimate around eight million men worldwide returned home permanently disabled after the First World War. Although the advanced weaponry caused more wounded, the improvement in the trenches' healthcare and medical care systems led to an unprecedented number of war disabled. For these soldiers, the war would never be over since they could never escape their suffering. ${ }^{2}$ While this was an international issue, each country dealt with disabled veterans in its own way, the State and the charitable and voluntary associations playing a more or less significant role with different political, social and economic consequences. ${ }^{3}$ Despite different measures, the aim was to reintegrate disabled ex-servicemen into civilian life, allowing them to be economically independent. Therefore, rehabilitation programs played a major role in reintegrating disabled veterans and reinstating their masculine role as citizens. ${ }^{4}$ The success of rehabilitation, however, varied from one country to another, with disappointment and frustration being expressed in different ways.

According to Deborah Cohen, the British state was rather negligent and failed to fulfil its obligation of rehabilitation and employment of disabled ex-servicemen. Thus, reintegration resulted in voluntary and philanthropic efforts, and disabled veterans lived

\footnotetext{
${ }^{2}$ Note: Historical terminology concerning disability is used in this article. J. Bourke, Dismembering the Male: Men's Bodies, Britain, and the Great War (London: Reaktion Press and Chicago: University of Chicago Press, 1996); D. Cohen, The War Come Home: Disabled Veterans in Britain and Germany, 19141939 (Berkeley: University of California Press, 2001), 1.

${ }^{3}$ P. Verstraete, M. Salvante and J. Anderson, 'Commemorating the disabled soldier: 1914-1940', First World War Studies, 6:1 (2015), 1-4, <http://dx.doi.org/10.1080/19475020.2015.1047464> [accessed 12 January 2017].

${ }^{4}$ W. J. Gagen, 'Remastering the Body, Renegotiating Gender: Physical Disability and Masculinity during the First World War, the Case of J. B. Middlebrook', European Review of History: Revue européenne d'histoire, 14:4 (2007), 525-541, <http://dx.doi.org/10.1080/13507480701752169> [accessed 12 January 2017]; A. Carden-Coyne, The Politics of Wounds: Military Patients and Medical Power in the First World War (Oxford: Oxford University Press, 2014), 341-2.
} 
on the edge of society with fewer legal rights than their European counterparts. Despite this situation, they remained silent and loyal to the King. In contrast, the German state established occupational retraining and free medical care, regulated important pensions, and secured employment. Regardless of their reintegration in the economy, disabled veterans still turned against the state by joining radical movements. ${ }^{5}$ Similarly, in Italy, civil society initially organised rehabilitation and vocational training, but then the state established a series of laws giving considerable medical rights and financial assistance to disabled soldiers. Nonetheless, the veterans saw these measures as insufficient and supported the rising fascist movement. ${ }^{6}$ On the other hand, in France, from 1916 onwards, the state standardised and coordinated, through the Office National des Mutilés, a large number of re-educational schools. There was a clear desire for mass rehabilitation to form 'new men'. Only a small fraction of disabled veterans was re-educated, and they still experienced difficulties in integrating into the saturated labour market. ${ }^{7}$

In Portugal, disability history and particularly war disability is under-researched. Two historians uncovered new data by including war-disabled veterans in their analyses. Cláudia Ribeiro focused on the care for 'abnormal' people in Casa Pia, ${ }^{8}$ while Sílvia Correia analysed First World War memory in Portugal, describing the veterans' movements (Great War Combatants League) and studying veterans' legislation. ${ }^{9}$ Despite these recent works, an analysis of the efforts done in Portugal to reintegrate disabled

\footnotetext{
${ }^{5}$ Cohen, $2-12$.

6 M. Salvante, "Thanks to the Great War the blind gets the recognition of his ability to act": the rehabilitation of blinded servicemen in Florence', First World War Studies, 6:1 (2015), 21-35 <http://dx.doi.org/10.1080/19475020.2015.1047892> [accessed 12 January 2017].

${ }^{7}$ M. Price, 'Bodies and Souls: The rehabilitation of Maimed Soldiers in France and Germany during the First World War' (Ph.D. diss., Stanford University, 1998) In ProQuest Digital Dissertations [database online]; <https://search.proquest.com/docview/304455312?accountid=28004> [accessed 2 February 2017]. ${ }^{8}$ Portuguese secular institution founded in 1780 by Pina Manique under the reign of Maria I to educate orphans and to rehabilitate beggars and idlers through work. C. P. Ribeiro, 'Os Outros... A casa Pia de Lisboa como espaço de inclusão da diferença’ (PhD diss., Universidade do Porto, 2009).

${ }^{9}$ S. Correia, 'Políticas da memória da I Guerra Mundial em Portugal 1918-1933: entre a experiência e o mito’ (PhD diss., FCSH-UNL, 2010).
} 
veterans into civilian life has yet to be made. This article seeks to fill this gap.

It first discusses some aspects of Portuguese participation in the Great War, including rough figures on disabled veterans. Secondly, it considers what was done regarding rehabilitation by looking into two re-education institutes. As members of the Permanent Inter-Allied Committee on Medical Care of the Disabled, the directors and doctors of these institutes were aware of what was being done abroad concerning disabled veterans. They wrote regularly about their work there and presented the stories of some of the disabled veterans' re-education. These primary sources are critically analysed to assess the success of these institutes. Finally, this text evaluates the state's intervention to provide economic and social support through the creation of disability pensions and by giving these veterans access to civil servant positions. As is demonstrated, the measures taken were insufficient to rehabilitate disabled ex-servicemen, who were then consigned to oblivion.

To achieve these goals, a qualitative analysis of a series of primary sources was conducted by researching several archives, namely the Portuguese Historical Military Archive (PT/AHM) and the National Archive (Torre do Tombo, PT/TT). This article is chronologically confined to a ten-year period, between 1917 , when the first disabled veteran started his rehabilitation process, and 1927, when the Disabled Code was published. The object of study of this article is physically disabled veterans, including those with visual and auditory disabilities, but excluding respiratory and psychological disorders as veterans suffering from these diseases had to fight in another specific way to be recognised as war victims. This analysis does not focus on veterans' organisations, or pension legislation. 


\section{Portugal and the Great War}

Portugal participated in the Great War with the Allies from September 1914 until the end of the conflict, deploying over 49,000 men to Angola and Mozambique to reinforce its military presence in these colonies. Following the German declaration of war, over 56,000 men were sent to the Western front from January 1917 onwards, although most of them never understood why they were fighting in France. The then recently established and unstable Republic believed this could be an opportunity to strengthen the political regime and reinforce its diplomatic role in Europe. ${ }^{10}$ Nevertheless, the Portuguese participation in the European theatre of war remained a controversial issue, with political, economic and social consequences. Portugal was a rural country, living mainly on agriculture, fishing and hunting, where three out of four men were illiterate. During the war, there was a lack of raw materials and the cost of living increased, leading to social unrest and the outburst of a revolution (December 1917). ${ }^{11}$ It was in this context of political, economic and social crisis that disabled servicemen returned home.

Statistical data concerning disabled Portuguese veterans should be approached with caution as it varies from one source to another. Official statistics of the Portuguese Army mentioned 7,272 disabled men in the Western front between March 1917 and April 1919, of which 5,737 were considered 'incapable of all service' by the medical boards. ${ }^{12}$ Graphic 1 reveals the evolution of these numbers, which were at its highest between September 1917 and August 1918, when the Portuguese participation in the battlefields was greatest. As for those who fought in Africa, the figures are less known but point to

\footnotetext{
10 A. Afonso and C. de M. Gomes, Portugal e a Grande Guerra 1914-1918 (Vila do Conde: Verso da História, 2013), 103-6; 140-9; 522.

11 Ibid., 320, 374-7, 444-52.

12 Portuguese troops arrived in France from February 1917 onwards but these statistics only started in the following month. Most of the troops returned to Portugal between March and May 1919, although April is the last month mentioned: Serviços de Estatística e Estado Civil do CEP, Livro de Estatística do CEP, PT/AHM/DIV1/35/1401/6.
} 
372 disabled veterans from Angola and 1,283 from Mozambique. ${ }^{13}$ Therefore, the number of disabled veterans was less than 9,000 , or about 8.5 percent of the mobilised men. Once again, although these figures can be questioned, ${ }^{14}$ it seems clear that the number of disabled soldiers in Portugal was lower than in other countries ${ }^{15}$ and fewer than the 18,000 men mentioned in newspapers to demand for war reparations. ${ }^{16}$ This last number is clearly exaggerated, probably to obtain higher war reparations and, in this newspaper article in particular, to sustain the idea that many men were expecting to receive a pension.

[INSERT GRAPHIC 1 HERE]

Graphic 1: Disabled veterans from the Portuguese Expeditionary Corps (Western Front)

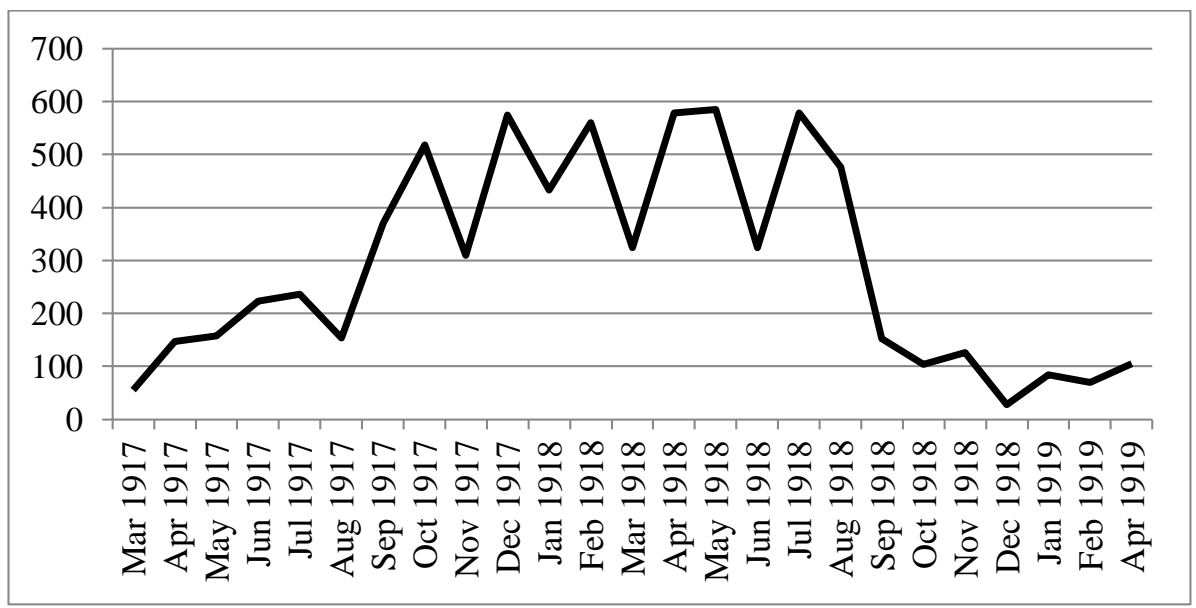

13 People from Angola and Mozambique were also engaged in the Portuguese army but were rarely mentioned in statistics, especially on disability: Afonso and Gomes, 522.

${ }^{14}$ Post-war government statistics were not always considered objective. In the case of France, the problem was underlined by Antoine Prost when he analysed the number of war victims and disabled veterans: A. Prost, 'I. Démographie : anciens combattants et victimes de guerre dans la population française', in Les anciens combattants et la société française 1914-1939, Tome II : Sociologie (Paris : Presses de Sciences Po, 1977), 3-27.

15 John Horne mentioned 8000,000 disabled veterans worldwide, 750,000 from Great Britain and 1 500,000 from Germany. In France, in 1922, over 1 100,000 veterans received a disability pension: J. Horne, 'The living', in The Cambridge History of the First World War, ed. by Jay Winter, volume III Civil Society (Cambridge: Cambridge University Press, 2014), 600; Prost, 19.

16 'Os mutilados e inválidos da guerra procuraram ontem ser recebidos pela comissão encarregada de codificar toda a legislação sobre o assunto', Unknown Newspaper (1926), PT/TT/MI-DGAPC/2/706/310; L. Além, 'Mutilados e inválidos, os 10.000 parasitas da verdadeira Leva da Morte', Unkown Newspaper (1926), PT/TT/MI-DGAPC/2/694/213. 
Source: 7,272 cases. PT/AHM/DIV1/35/1401/6

Unfortunately, these rough numbers include all types of disabilities, namely psychological traumas and respiratory diseases, making it impossible to determine exactly how many soldiers had physical disabilities. Bearing these reduced figures in mind, we can still question what was done to help physically disabled veterans reintegrate into civilian life in Portugal. In contrast with other nations, institutes for disabled civilians did not exist in Portugal prior to the war, so disabled veterans had no specific institution to go to for assistance. ${ }^{17}$ It is in this context that two institutes emerged to devote themselves to this issue temporarily, with the collaboration of the Portuguese state, in a domain entirely new in this country.

\section{Disabled veterans at Saint Isabel's Institute}

In Portugal, as in other countries, there were no measures in place that foresaw the return of soldiers who were considered, by the medical boards, incapable of earning a living due to their disability. According to Ribeiro, Doctor Costa Ferreira was one of the first persons to worry about these men in $1916 .{ }^{18}$ As the Director of Casa Pia in Lisbon, he suggested adapting a part of the Saint Isabel's Medical-Pedagogical Institute to receive physically disabled veterans. This Institute, one of several administered by Casa Pia, had been created by Doctor Costa Ferreira and had opened in 1915 to educate 'abnormal' children. For this doctor, a part of the Institute could become a hospital-school where disabled veterans could receive treatment since it already possessed experienced medical staff and equipment. Doctor Costa Ferreira was well aware of the situation in other countries as he

17 J. G. C. Melo, Mutilados da Guerra e Acidentados de trabalho: da Reeducação Profissional (Coimbra: Casa Tipográfica de Alves \& Mourão, 1923), 25-7.

${ }^{18}$ C. P. Ribeiro, 'Os heróis que a Guerra invalidou... reeducar o soldado no Instituto de Mutilados de Santa Isabel (1917-1921)', Revista da Faculdade de Letras História, III série, vol. 9 (2008), 315. 
was one of the vice-presidents of the Permanent Inter-Allied Committee on Medical Care of the Disabled. ${ }^{19}$ Furthermore, in January 1917, Doctor Fernando Palyart Pinto Ferreira who also worked in Saint Isabel, visited three similar institutes in France,${ }^{20}$ reporting how the disabled veterans there were being rehabilitated, which helped to develop this field in Lisbon.

The Minister of War and the Minister of Internal Affairs approved the admittance of disabled veterans at Saint Isabel's Institute until the opening of the Arroios Reeducation Institute for the War-Disabled. ${ }^{21}$ Consequently, Saint Isabel's Institute started receiving disabled veterans on 16 November 1917. This Institute was financially supported by the Portuguese state and private institutions, as well as by individuals across the country and from abroad. (The Portuguese community in Brazil was quite generous). ${ }^{22}$

To increase the number of contributions and to draw society's attention to disabled veterans, the Institute used propaganda and media exposure. Several newspapers published articles on politicians' visits, as well as on the positive aspects of reeducation. ${ }^{23}$ Moreover, the director of the physiotherapy service, Doctor José Pontes, wrote regular chronicles about the Institute for the newspaper, A Capital, which was later published in a book. Pontes was aware of the veterans' rehabilitation programs abroad as he had previously worked at the Parisian military hospital of Val de Grâce and participated in several meetings of the Permanent Inter-Allied Committee on Medical Care of the Disabled, becoming its vice-president after the death of Doctor Costa Ferreira

\footnotetext{
19 See Revue interalliée pour l'étude des questions intéressant les mutilés de la guerre <http://catalogue.bnf.fr/ark:/12148/cb43649608b> [accessed 9 May 2018].

20 The Institut Nationale Professionnel des Invalides de la Guerre, the Laboratoire des recherches sur le travail professionnel au Conservatoire National des Arts et Métiers and Val de Grâce re-educational section. Ribeiro, 'Os heróis...', 316-21.

21 After its opening, disabled veterans did not stay longer than a fortnight at Saint Isabel's. 'Decreto n³.751', Diário do Governo, 12 (1918), 35-6.

22 Ribeiro, 'Os heróis...', 322-325.

23 This situation was not unique to Portugal, as other media worked on the image of disabled war veterans.
} 
(1922). ${ }^{24}$ The veterans saw him as 'the friend of our heroic war-disabled', who dedicated himself to their cause, including in the Parliament. ${ }^{25}$

Pontes' romanticised and naïve writings focused on disabled veterans that successfully reintegrated themselves after being admitted at Saint Isabel's Institute, leaving aside those who could not be rehabilitated, as well as those who had not succeeded. His writings reflected the image he wanted to pass on to the Portuguese society: how soldiers became disabled during the war, how they were treated in this Institute and what their situation was when they left. Some reintegration stories of disabled veterans were chosen for this article because they provided information on the treatments and procedures at the Saint Isabel's Institute, even if not in the long-term. To deepen our analysis, personal details were collected in individual military records (boletins individuais).

From Pontes' writings, we know that this Institute admitted war disabled veterans with small injuries or amputations, who received moral support, none or only minor physiotherapy, therefore quickly returning home and to previous working activities, as the following two cases demonstrate. Private Campos had neuralgia on his hand, a condition that was easily managed with massages, which allowed him to continue working the land. ${ }^{26}$ Corporal Torre's right index and middle fingers had been amputated in France due to shrapnel. Nevertheless, he could still carry out all movements and continue working as a cabinetmaker. ${ }^{27}$

Other disabled veterans needed a longer rehabilitation period, as they had to get used to a prosthesis before going back to work. Private E. Duarte, a single farmer and carpenter from the district of Coimbra, believed he would never work the land again

\footnotetext{
${ }^{24}$ Livro de Actas da sub-comissão técnica, Acta nº1, 19.11.1919, PT/AHM/DIV1/35/442/3.

25 'Ouvindo "alguém!", Vítimas da guerra “... e cuidar dos vivos”, 59 (1933), 3.

${ }^{26}$ Pontes, 56-8.

${ }^{27}$ Ibid., 73-8.
} 
because he only had his left thumb, one phalanx of his left index finger and a part of his right middle finger. According to Doctor Pontes, firstly, this veteran's morale was boosted to accept his disability. Afterwards, he was taken into the garden where he was given a hoe along with a leader glove and a 'working hand' both adapted to his hands. The doctor reported that when Duarte realised he could use the hoe to dig, his face changed becoming more and more joyful each time he broke up the ground. ${ }^{28} \mathrm{He}$ went home and kept practising his 'working gloves' over the next two months. ${ }^{29}$ At the beginning of 1918, Doctor Costa Ferreira conducted several tests to count the amount of movements Duarte could do with the 'working gloves' and compard them with the movements of a 61-year-old man. Ferreira concluded that the disabled veteran was in fact more responsive than the able-bodied one. ${ }^{30}$

In other cases, rehabilitation was not only meant to help people adapt to the prosthesis but also to teach them new occupations. Private Robalo, a single, 24-year-old man from the district of Castelo Branco, suffered an amputation up to the upper third of his forearm due to an accident with a grenade in France. At Saint Isabel's Institute, he learnt how to peel potatoes 'faster than an able-bodied man' without even using a prosthesis. According to Doctor Pontes, this was an example of how, if the new occupation was well chosen, some disabled veterans might not even need a prosthesis to continue working. Robalo became an assistant cook at the Institute, learnt how to read and enjoyed long talks with the nurse who taught him to be less churlish. He was given as an example of one of the first men to rebuild himself at Saint Isabel's. By the end, he had an improvised artificial arm with a piece of wood, two pieces of iron and a hand in

28 Ibid., 24; Boletim individual de E. Duarte, PT/AHM/DIV/1/35A/2/14/12623; Instituto MedicoPedagógico da Casa Pia de Lisboa, Wounded of the war at the Institute of Sta Izabel (Lisboa: Imprensa Libanio da Silva, 1918), 18-21.

${ }^{29}$ Usually, disabled veterans were allowed to go back home during two or three months to verify if they had been able to adapt to the prosthesis. Pontes, 131.

${ }^{30}$ Instituto Medico-Pedagógico da Casa Pia de Lisboa, 22-5. 
leather so that he could work 'almost as before'. ${ }^{31}$ There were other successful cases, namely that of Private J. Duarte, a single man from the Leiria district, who, after an accident with a grenade in France, had lost sight in one eye, suffered shrapnel wounds in his face and neck, and had the fingers of one hand amputated. He wanted to 'return to his folks' as quickly as possible. Thus, he had an 'artificial hand', made to his size, so he could harvest fruits, which were largely produced in his home region. ${ }^{32}$

Some veterans were happier than others with their new occupation. Private Costa, a single man from the Aveiro district who used to work the land, became a barber, an occupation he had carried out in Africa during the war, (he had shaved a number of men there) and which he enjoyed. Later on, he was sent to France, where his leg was amputated due to an accident with a grenade, while on duty. He received an artificial leg at St Isabel's with which he was able to walk without crutches. ${ }^{33}$ In contrast, Private Vieira, a single man also from the Aveiro district, admitted he was disappointed at not becoming a liner boat pilot. Disabled in the Western front due to an elbow ankylosis caused by a mortar, the Private started teaching his comrades at Saint Isabel's and later became a primary school teacher. ${ }^{34}$

In other cases, without possible treatments, rehabilitation was more complex since veterans had to learn how to live with their disability. This was the case of Private Sequeira, from the Leiria district, who got married during the war and lost his sight in combat in France. ${ }^{35}$ Completely blind, ${ }^{36}$ the medical board considered him incapable of

\footnotetext{
${ }^{31}$ Pontes, 29-33, 190; Boletim individual de N. Robalo, PT/AHM/DIV/1/35A/2/11/09170.

32 Pontes, 54, 60; Boletim individual de J. Duarte, PT/AHM/DIV/1/35A/2/02/009981.

${ }^{33}$ Pontes, 139-141; Boletim individual de J. da Costa, PT/AHM/DIV/1/35A/2/16/14428.

${ }^{34}$ Pontes, 10, 36-38; Boletim individual de J. Vieira, PT/AHM/DIV/1/35A/2/14/12081.

${ }^{35}$ Also according to Ribeiro, he also received a donation from D. Emília Bensaúde of 2.500 escudos, which allowed him to buy a house and some land. C. P. Ribeiro, 'Os Outros', 335.

${ }^{36}$ Army statistics mention a reduced number of Portuguese blind veterans, around 20, and only two of these were completely blind. They were entitled to a disability pension, even if they were only partially blind. This low figure did not permit the creation of specific rehabilitation institutions or associations for blind veterans, as in other countries. Letter from Doctor Artur Eugénio de Almeida e Silva to the Portuguese War Minister, 03.03.1919, PT/AHM/DIV/1/35/1275/07.
} 
earning a living, like most of the other veterans previously mentioned. Despite his impairment, this former fisherman was described as quite joyful during his stay at the Saint Isabel's Institute. According to the account, he stayed with his dark glasses at the back of the classroom, where he worked every day. He made nets and net bags using a piece of wood and a special needle. The bags were very well made, so he started selling them. ${ }^{37}$ Francisco Grandella accepted these bags to sell at his department store, without any commission. Thus, Private Sequeira returned home, where he continued making these bags which were then sold in Lisbon. ${ }^{38}$

For many veterans, staying at the Institute, isolated from their families, made them feel homesick. Several of the stories told by Doctor Pontes revealed the veterans' fear of no longer being able to work or be the breadwinners of their households. Thus, the institute's doctors also tried to find new employment for disabled veterans. With the help of the Saint Isabel's Institute, Private Abrantes found a job in Lisbon which was suitable for him and his shoulder disarticulation. ${ }^{39}$ Private Melo recovered his movements after being injured on the wrist and right ankle because of a mortar. The director of the Institute promised him a job as a postman near his village, since his parents were on their own after the death of his two sisters. ${ }^{40}$ Most veterans were illiterate, so the doctors also helped with the necessary formalities for them to obtain a disability pension. ${ }^{41}$ These cases reveal how the institution not only worked as a medical care centre or rehabilitation institute but also helped in social welfare.

This positive vision was not shared by all the doctors who played a role in the re-

\footnotetext{
${ }^{37}$ Pontes, 17-22; Boletim individual de M. F. Sequeira, PT/AHM/DIV/1/35A/2/02/01132.

${ }^{38}$ Pontes, 52.

${ }^{39}$ Pontes, 89.

${ }^{40}$ Ibid., 108-9; Boletim individual de M. C. Melo, PT/AHM/DIV/1/35A/2/16/14083.

${ }^{41}$ From 1918 onwards, in addition to the retirement pension, disabled veterans were entitled to a disability pension if they had a disability of at least 20 percent. 'Decreto nº 4.868', Diário do Governo, 217 (1918), 1753-4.
} 
education of disabled veterans. Doctor Tovar de Lemos, director of the Arroios Reeducation Institute and also a member of the Permanent Inter-Allied Committee on Medical Care of the Disabled, believed the rehabilitation was not 'well done' at Saint Isabel's, considering that disabled veterans from this Institute were used to beg in the streets of Lisbon. ${ }^{42}$ Furthermore, once disabled veterans in re-education institutes started receiving the same wages as when they were in the front, ${ }^{43}$ many took advantage of the situation. Doctor Costa Ferreira agreed that some disabled veterans wanted to learn several crafts so they could stay at Saint Isabel's for as long as possible. ${ }^{44}$ By the end, Ferreira was not able to hide his dissatisfaction concerning the Institute he was directing, mentioning that most veterans were illiterate and did not want to learn how to read or write. Therefore, for him, the results concerning professional re-education were limited, as shoe and basket maker were the most useful occupations for disabled veterans when they returned to their rural areas. ${ }^{45}$

Despite Doctor Costa Ferreira's disappointment, St Isabel's Institute had some success. It was Portugal's first rehabilitation institute and there disabled veterans realised they were capable of doing something. They were also able to share their feelings and learn their rights. It also drew society's attention to war disabled men with several newspapers regularly publishing articles on them. As Ribeiro noted, above all, a group of doctors working on this field was formed, contributing to the discussion and regulation of most of the Portuguese bills and laws for disabled war veterans. Finally, it also helped to establish the Arroios Re-education Institute for the War-disabled, as both institutions worked together until 31 July 1919, when Saint Isabel's stopped caring for war disabled

\footnotetext{
${ }^{42}$ Livro de Actas das Sessões da Comissão de Estudo das Condições de Reforma e Pensões Temporárias e Assistência a Fornecer aos Mutilados da Guerra, Acta n², 24.11.1919, PT/AHM/DIV/1/35/442/3.

43 'Decreto nº.154', Diário do Governo, 89, (1918), 517.

${ }^{44}$ Livro de Actas das Sessões.

${ }^{45}$ Ribeiro, 'Os heróis...', 330.
} 
ex-servicemen. ${ }^{46}$

\section{Arroios Re-education Institute}

In April 1917, the voluntary organisation of the Crusade of Portuguese Women ${ }^{47}$ decided to create the Arroios Re-education Institute for the War-disabled under the guidance of Doctor Tovar de Lemos. ${ }^{48}$ The aim was to provide all necessary treatments, prosthesis and re-education so physically disabled veterans could have an occupation and not feel like a weight on society. ${ }^{49}$

Since its opening, this Institute worked with three different sections: firstly, the professional orientation section, at the Saint Isabel's Institute, where disabled veterans stayed for a maximum of 15 days to evaluate their ability to work and to define a convenient occupation; ${ }^{50}$ then they would pass through the physical re-education section in Arroios (Lisbon), where they would have physiotherapy and adapt to their prosthesis (if they had any); finally, they would go to the professional re-education section (also in Arroios), where they would prepare themselves to return to their previous occupation or, if needed, learn a new one. Although there is no mention of how the new occupation was chosen, it is stated that in this last section, men could have primary school lessons (as the

\footnotetext{
46 PT/AHM/DIV/1/35/1275/07.

47 In March 1916, after the declaration of war, a group of women from the Portuguese high society created the Cruzada das Mulheres Portuguesas. The wife of the President of the Republic was among its members. With different commissions, this female organisation aimed at supporting soldiers that had been sent to the front and their families through different activities, namely by distributing clothes and donations, by creating day care centres or having wartime godmothers. Cruzada das Mulheres Portuguesas (Comissão de Propaganda e Organização de Trabalho), Relatório e contas apresentadas à Assembleia Geral de 9 de Março de 1917, Gerencia de 1916 a 1917 (Lisboa: n.ed., 1917); Cruzada das Mulheres Portuguesas, Comissão de Assistência aos Filhos dos Militares Mobilisados ou em Campanha, Relatorio e Contas, Gerencia de 1917 a 1918 (Lisboa: n.ed., 1918).

48 The Crusade and the political bonds with the President of the Portuguese Republic were not always positive, due to political changes. As a consequence, the Institute of Arroios was managed by the Minister of War between January 1918 and March 1920. Correia, 'Políticas da memória', 100-113.

49 C. P. Ribeiro, 'Os "maluquinhos" de Arroios... A reeducação dos mutilados da Guerra no Instituto de Arroios (1916/1923)', Revista Portuguesa de História, XLV (2014), 69-94.

${ }^{50}$ Melo, 27.
} 
majority was illiterate) and commerce, industry or elementary training in agriculture. ${ }^{51}$ Between May 1918 and December 1919, over 43,000 treatments were done in the physical re-education section and over 59,000 hours of classwork in the professional reeducation section. ${ }^{52}$

Doctor Tovar de Lemos sent a listing of mutilated men that had been admitted to the Arroios Institute to the director of the statistical services of the Portuguese Expeditionary Corps. From this listing, dating from 18 June 1920, seven men had been wounded in Africa, 427 in France and seventeen in Portugal. ${ }^{53}$ This means that in two years' time, the Arroios Institute received at least 434 disabled veterans from the Great War. Unfortunately, this list does not give any information on their recovery status.

In 1921, a board visited the Arroios Institute and concluded that it had failed its reeducation mission. At the time, Doctor Tovar de Lemos stood up for his work at the Institute, revealing some figures on the physically disabled and their re-entry into the labour market. First, he mentioned that there were 403 enrolments in different reeducation courses, although only one fifth obtained good results, partially because of the high number of illiterate men and also because these were not compulsory classes. Among the offered choices, primary school, agriculture and shoemaking had the highest attendance with 39.5, 26.3 and 9.9 percent of registrations but with different achievement rates (18.9 percent for primary school courses, 23.6 percent for agriculture and 40 percent for shoemaking). ${ }^{54}$ Secondly, he revealed data obtained through an inquiry form he sent to the discharged disabled veterans from the Institute asking, among other questions, what

\footnotetext{
51 T. de Lemos, A Reeducação Profissional dos nossos Mutilados de Guerra (Lisboa: Comissão de Enfermagem da Cruzada das Mulheres Portuguesas, 1918), 46-49.

${ }^{52}$ Cruzada das Mulheres Portuguesa, Instituto de Arroios, Terminada a Guerra, a obra de reeducação dos mutilados da guerra. Sua integração na vida social (resultados obtidos. O que é preciso fazer) (Lisboa: A Americana, 1920), 16-22.

53 PT/AHM/DIV/1/35/1486.

${ }^{54}$ Cruzada das Mulheres Portuguesas, Instituto de Arroios, Mutilados de Guerra, Relatório da $3^{a}$ Secção (reeducação profissional) (Lisboa: Tip. Lusitania, 1921), 8.
} 
their occupation before and after the war was, in case they were back to work, and what was their salary. These answers, along with those from disabled veterans still at the Institute revealed that it had received 465 men between May 1918 and December 1920 (Table 1).

[INSERT TABLE 1 HERE]

Table 1: Situation of disabled veterans from the Arroios Institute (December 1920)

No. \%

\begin{tabular}{|c|c|c|c|c|c|}
\hline Died & 6 & 1,3 & & & \\
\hline Do not work & 10 & 2,2 & & & \\
\hline Unknown situation & 66 & 14,2 & & No. & $\%$ \\
\hline Still at the institute & 53 & 11,4 & Same occupation & 216 & 65,5 \\
\hline Do work & 330 & 71,0 & New occupation & 114 & 34,5 \\
\hline Total & 465 & 100 & Total & 330 & 100 \\
\hline
\end{tabular}

We know from the previous listing that at least seventeen disabled men had been wounded in Portugal and not in the war, but Doctor Tovar de Lemos did not mention it. According to our calculations of Lemos' data, only ten men declared that they did not work, which is a minority. This figure could be higher, however, since 66 others did not deliver the inquiry form, and thus their situation remained unknown. In addition, 53 men were still receiving treatment at the Institute, and six died. Thus, 330 men declared having a working activity, which is a positive figure. From these working men, almost two-thirds maintained the same activity after their injuries; over 60 percent continued 'working the land'. This means that one-third found a different occupation adapted to their new 
condition. The type of activity was also mentioned, revealing new occupations like working in the post and telegraph office, or being a shepherd or a doorman; however, the weight of other occupations was much higher (public workers, basket makers and shoemakers). ${ }^{55}$

For Lemos, the men that passed through the Arroios Institute had the opportunity to re-educate themselves if they wanted to. Those who did so found fine working opportunities with good wages. He believed that, even if the work at the Institute was not perfect, something had been done for disabled veterans, in contrast with the situation of those affected by tuberculosis or psychological traumas, who were still demanding that their situation gain recognition. ${ }^{56}$ Additionally, Lemos criticised those veterans who took advantage of their disability, namely those who wanted to remain at the Institute after completing their rehabilitation and those who did not want to re-educate themselves because they were expecting to have a disability pension or a public servant position. ${ }^{57}$ These criticisms were not unfounded since those who stayed at the Institute received a wage, food and accommodation. On the other hand, some did not want to remain in Lisbon for too long, in a foreign environment away from their family and home.

Unfortunately, the data does not allow us to know more about the veterans' social reintegration after leaving the Institute. According to Lemos' inquiry, the majority of disabled veterans found an occupation, but did they work full or part-time? And were their wages enough to support them and their families? Newspapers mentioned fewer cases of disabled veterans at the Arroios Institute than at Saint Isabel's, which does not allow us to deepen this question. Moreover, articles written by disabled veterans criticised the work of the Institute, complaining about the prevailing anarchy, the lack of discipline,

\footnotetext{
55 Ibid., 33-8.

56 Ibid., 39-40.

${ }^{57}$ Ibid., 17; Livro de Actas das Sessões.
} 
the waste of money, the poor medical treatments with some maimed waiting over two years for their prosthesis, and the absence of professionals in re-education. ${ }^{58}$ Some went even further, declaring that not even one disabled man had left the Institute re-educated. Accused of being a 'joke' and of only giving some nursing treatments and some lessons to illiterate veterans, the Arroios Institute started receiving war orphans at the end of $1921,{ }^{59}$ but it kept on receiving civilian disabled individuals with work injuries. ${ }^{60}$ Some veterans kept living in the building in the 1920s but, progressively, rehabilitation was left aside. $^{61}$

The Portuguese state played a minor role in these rehabilitation institutes, only giving financial support and managing the Arroios Institute from January 1918 to March 1920. There was no national coordinated or coherent rehabilitation programme for war disabled veterans as in France or Belgium. ${ }^{62}$ During and after the Great War, the role played by the Portuguese state concerning disabled veterans varied along with political regimes, therefore not having a continuous line of action.

\section{Government measures}

One of the measures taken by the Portuguese state was establishing the right for disabled veterans to receive the same wage during rehabilitation that they had been receiving while in the front. Nonetheless the newspaper $O$ Mutilado $^{63}$ (the maimed) mentioned the case of Lourenço, a man who had lost his right leg and had been admitted to the Arroios

\footnotetext{
58 'O Instituto para Reeducação dos Mutilados de Guerra', O Mutilado, 14 (1921), 6.

59 'Depois da tormenta', Vítimas da Guerra "... e cuidar dos vivos", 76 (1933), 1, 3; Cruzada das Mulheres Portuguesas, Boletim Mensal $n^{\circ} 7$ (Lisboa: Secretaria da Cruzada, 1921), 149-50.

${ }^{60}$ Melo, 51.

${ }^{61}$ Actas da Direcção, Pasta 2, Arquivo da Liga dos Combatentes - Cruzada das Mulheres Portuguesas.

62 Price, 77.

${ }^{63}$ This newspaper was published between July 1920 and April 1921 with only 14 issues. Directed by Alberto Baptista Alvares and edited by António Augusto Barnabé, it was partially financed by publicity and subscriptions. The newspaper informed the maimed on their rights and demands and did not hesitate to criticise the Portuguese state or rehabilitation institutes.
} 
Institute, but who did not receive his wage between June and October 1918, despite having written several letters. ${ }^{64}$

Also in 1918, the Portuguese government created disability pensions (in addition to retirement pensions) for veterans with a disability of at least twenty percent. The pension was calculated according to the percentage of loss of functional capacity of a normal man, following the French scale (barème). The veteran would lose the pension if he refused to be re-educated or to use a prosthesis. Five years later, a medical board should re-evaluate the disabled veteran and decide whether he could keep the pension or not. ${ }^{65}$ This law was changed in the following years, also to include sick veterans. ${ }^{66}$

This legislation had several limitations and probably did not include all disabled veterans. Firstly, considering that the majority of men were illiterate, it was certainly difficult for them to request and obtain a disability pension on their own, which required a certain number of documents. In addition, the process took a long time. Several sources $^{67}$ suggest that it took months, and in some cases even years, to get a disability pension, which led some to believe that it was necessary to know influential people to obtain one. ${ }^{68}$ Some veterans were so desperate they saw suicide as the only solution. This was the case of soldier Guindães who had progressively lost his sight, becoming completely blind after surgery during the war. ${ }^{69}$

We can also question the amount of these disability pensions and whether they were sufficient to provide a living for disabled veterans and their families. It seems that this was not the case, according to Doctor Tovar de Lemos, Doctor José Pontes, the Crusade

\footnotetext{
64 'A quem competir providenciar', O Mutilado, 2 (1920), 3.

65 'Decreto n'4.868', Diário do Governo, 217 (1918), 1753-4.

${ }^{66}$ Correia, 'Políticas da memória', 114-38.

${ }^{67}$ Liga dos Combatentes da Grande Guerra, Relatório das Gerências de 1923 a 1928 (Lisboa: Imprensa da Armada, 1929), 34; 'Justiça!', Vitimas da Guerra “... e cuidar dos vivos ”, 10 (1931), 4; 'Porquê?', Vítimas da Guerra “... e cuidar dos vivos”, 11 (1931), 1; Clipping on First World War disabled veterans, Library of the Combatants League in Lisbon.

${ }^{68}$ L. de Gusmão, Visão da guerra (Lisboa: Emp. Nac. de Publicidade, 1932), 293-4.

${ }^{69}$ Z, 'A situação dos inválidos de guerra', Unkown newspaper, 8.04.1925, PT/TT/MI-DGAPC/2/692/164.
} 
of Portuguese Women, and several newspaper articles ${ }^{70}$. At a time when inflation was particularly high, 'meat and fish were inaccessible' on such low pensions, leaving disabled veterans in a 'situation of misery', 'only to starve to death' ${ }^{71}$ These accounts might have been exaggerated, but the reality was that these pensions were hardly equivalent to a monthly wage. This can also explain why most disabled veterans at Saint Isabel's and the Arroios Institute seemed to have a working activity despite their disability. In this way, they would not only feel reintegrated and useful, but they would also be able to receive some extra money.

In addition to disability pensions, the Portuguese state enacted several laws giving preference to disabled veterans in access to civil servant positions in order to contribute to their reintegration into the labour market. For instance, law 993 from 1920 specified that disabled sergeants should be given preference for the first possible vacancies in public positions, after re-education and if they were able to work. As for maimed privates, they were given preference for less qualified public positions like school guard or janitor. $^{72}$ This law was changed several times in less than one year. First, it was proclaimed that all disabled veterans should have access to public positions. Those with over fifty percent disability should be placed without having to pass any public service exam if they had the required qualifications and physical ability to fulfil the position. All vacancies for guard, public servant and janitor in public services were exclusively reserved for disabled veterans. ${ }^{73}$ Later, in May 1921, it was proclaimed that disabled veterans should have priority in public vacancies if they had at least twenty percent

\footnotetext{
${ }^{70}$ Relatório da Comissão de Estudo das Condições de Reforma e Pensões Temporárias e Assistência a Fornecer aos Mutilados da Guerra, 20.3.1920, PT/AHM/DIV/1/35/442/3; Pontes, 7-8; Cruzada das Mulheres Portuguesas, Boletim Mensal $n^{\circ} 2$ (Lisboa: Secretaria da Cruzada, 1921), 28; Clipping on First World War disabled veterans.

71 'Triste situação', O Mutilado, 2 (1920), 1.

72 'Lei n993', Diário do Governo, 134 (1920), 873.

73 'Lei nº1.128', Diário do Governo, 57 (1921), 339.
} 
disability. If they became public servants, however, they would lose fifty percent of their disability pension. ${ }^{74}$

These laws, namely the process of selection, received a lot of criticism. ${ }^{75} \mathrm{~A}$ document sent to the Ministry of Finances on May 1921 included a list of disabled veterans asking for a public servant position at the ministry. The list contained eleven names, the desired position and the date of the request, all signed by a doctor. However, the reply to the document stated that the law should be respected and that only one of the positions was dependent on this ministry, not revealing if the position had been fulfilled by a disabled veteran. ${ }^{76}$ This indicates that the process of obtaining a civil servant position was a difficult one, where veterans had to wait for a vacancy which might not even be the one they required.

The absence of civil servant positions was a major complaint from disabled veterans, who even accused the Portuguese state of giving employment to women when they had not suffered as men had in the war. ${ }^{77}$ The newspaper $O$ Mutilado criticised particularly law 993, asking, for instance, 'Where are the vacancies?'. According to its articles, the years passed by and there were 'no vacancies' for disabled war ex-servicemen and this law, like others, remained only on paper. The newspaper revealed several examples of disabled veterans who asked for a civil servant position without obtaining it. ${ }^{78}$ In one case, refusal was justified by the fact that the man did not hold the relevant qualifications; but others were not even informed of the reasons behind their exclusion. ${ }^{79}$ We should keep in mind that the requests were done directly to the office offering the

\footnotetext{
${ }^{74}$ Military men that wished to remain in service could also find a suitable position in the army if their disability was between twenty and seventy percent. 'Lei nº1.170', Diário do Governo, 105 (1921), 750-2.

${ }^{75}$ Cruzada das Mulheres Portuguesas, Boletim Mensal $n^{o} 1$ (Lisboa: Secretaria da Cruzada, 1921), 12.

${ }^{76}$ Letter from the General Secretariat of the Ministry of Finance to the Exchequer, 27.05.1921, PT/TT/MFSG/001-66/18081.

77 Vitimas da Guerra “... e cuidar dos vivos”, 11 (1931), 1.

78 'A lei n'933', O Mutilado, 1 (1920), 3.

79 'Mais uma lei', O Mutilado, 10 (1921), 1.
} 
position, which would also make the decision. Even if occupying a civil servant position was an option, it is not possible to know how many disabled veterans actually obtained one and if it helped them overcome their difficulties.

One may also ask why the actions of the Portuguese state concerning disabled veterans were limited. First, the Portuguese economic situation imposed restrictions to actions in favour of these men. During the war, the scarcity of goods and strong inflation constituted severe problems in Portugal, a country which was dependent on the import of cereals and coal. The participation in the Great War also contributed to the increase of public expenditure. To finance military expenses, Portugal contracted several war loans from Great Britain. After the conflict, this debt was nineteen million pounds sterling and Portugal was expecting to use part of the 49.5 million of war reparations to pay it off. By 1926 only a small amount of war reparations had been paid. As a consequence, interest kept increasing and so did the Portuguese debt to the British. This led to a trust crisis, the depreciation of the escudo (Portuguese currency) and uncontrolled inflation. The situation was worsened by the lack of important measures to control the economic and financial crisis as there were constant government turnovers (thirty-eight finance ministers between 1918 and 1923). All the expenses relating to disabled veterans could have been financed by the war reparations but they were paid off with significant delays and were included in the overall state revenue to balance its budget. ${ }^{80}$

Political instability was another factor that militated against the creation of a generous suite of legislation that favoured disabled veterans, especially if we take into consideration that several politicians had been against the participation in the First World War and, therefore, did not want to hear the veterans' claims, as they did not feel

\footnotetext{
${ }^{80}$ E. Mata and N. Valério, 'Capítulo X: a época das guerras e das crises' in História Económica de Portugal, uma perspectiva global (Lisboa: Editorial Presença, 1993), 181-7; J. da S. Lopes, 'Capítulo 8: Finanças públicas', in História Económica de Portugal 1700-2000, ed. by Pedro Lains and Álvaro Ferreira da Silva, vol. III O Século XX (Lisboa: ICS, 2005), 267-9.
} 
responsible for their condition nor their rehabilitation. Some governments did not follow the measures taken by their predecessors, leaving veterans feeling abandoned. ${ }^{81}$ This unsatisfactory legal protection contributed to the creation of the Liga dos Combatentes da Grande Guerra (Great War Combatants League) in 1924, which had, among its members, disabled veterans. ${ }^{82}$

The inadequate and insufficient reaction of the Portuguese state was also due to the difficulties that disabled veterans faced when trying to represent themselves as a group. Their number and influence were less important than in other countries. From the total number of disabled veterans (over 8,000 ), a large majority returned home without any reeducation, not demanding a disability pension, not participating in veterans' associations or activities, and not receiving newspapers, as most of them were illiterate. ${ }^{83}$

Despite their reduced number, a Disabled Congress was organised in Coimbra in January 1926 to stand for their rights. Doctor Pontes was among the participants of this Congress, where disabled veterans demanded the unification of the legislation and stronger action from the Portuguese State. ${ }^{84}$ In 1927, the Portuguese State published the Disabled Code, which was frequently restructured. Therefore, some disabled veterans continued complaining during the 1930s that the regulation was spread through different ministries and far from being applied. ${ }^{85}$ The majority of the men were illiterate and had no right to vote, so these disabled veterans had no political voice, no social representation and were soon forgotten.

\footnotetext{
81 J. do Monte, 'Inválidos de Guerra, elementos subsidiários para a solução das questões que lhes interessam', Vítimas da guerra “... e cuidar dos vivos”, 43 (1933), 2.

82 S. B. Correia, 'The veterans' movement and First World War memory in Portugal (1918-33): between the Republic and Dictatorship', European Review of History: Revue européenne d'histoire, 19:4 (2012), 534-535, <http://dx.doi.org/10.1080/13507486.2012.697872> [accessed 12 January 2017].

83 'Um dever', Vitimas da guerra “... e cuidar dos vivos”, 101 (1934), 1.

84 'O Congresso dos Mutilados e Inválidos da Guerra', A Guerra, 1 (1926), 13. 'O $1^{\circ}$ Congresso dos Mutilados e Inválidos da Guerra inaugurado na Sala dos Capelos da Universidade de Coimbra', A Guerra, 2 (1926), 13-17.

85 'II Congresso dos Combatentes portugueses (circular)', Vítimas da guerra “... e cuidar dos vivos”, 1 (1930), 2.
} 


\section{Conclusion}

In Portugal there were no previous re-education institutes for disabled people, so physically disabled veterans could only be re-educated in Lisbon, first at the Saint Isabel's Institute and then at the Arroios Institute. The first resulted from the work of progressive medical reformers and aimed at contributing to the emotional, psychological and physical recovery of disabled men, thus helping them find a way to earn a living and avoid begging or being a burden for the Portuguese state and society. In the first few months, the doctors' opinions on the re-education and rehabilitation of the disabled veterans were quite positive; the men received treatment and prostheses and learned how to work with them, either in their previous occupation, or in a new one. This perfect portrait might have been exaggerated as the director himself was disappointed with the results obtained, since most men remained illiterate and with manual occupations. Similarly, the director of the Arroios Institute also underlined this issue, adding that good achievement rates were low, especially in primary school classes. Overall, he believed that those who wanted reeducation managed to do it, and presented figures to sustain that the majority worked despite their disability. Both projects and expectations were high, but the results were partial because these institutes only operated for a limited period of time and a small number of disabled veterans took advantage of the services they offered.

Despite the lower number of disabled veterans in Portugal in comparison with other countries, the percentage that received re-education was perhaps even lower as these were the only two institutes for rehabilitation. The number of disabled veterans was not enough to convince other philanthropic organisations to devote their work to this cause. As a result, rehabilitation was not done in mass but instead, it was more personalised, as the 
doctors' accounts have revealed. Furthermore, there were no specialised institutions as in other countries, for example, for the rehabilitation of blind veterans.

The limited success of rehabilitation was not unique to Portugal; many American disabled veterans resisted re-education and never completed the courses, while others refused jobs. They also criticised the system for being too slow, ineffective and complained about low pensions, ${ }^{86}$ like the Portuguese, who were also discontented with measures taken by the Government to compensate them for their situation. Similarly, in Great Britain, disability pensions were lower than a regular wage, and many veterans had to fight to obtain a pension. They were asked to prove the extent of their injuries and had to present themselves regularly to medical boards that refused or lowered their pensions since the State hoped to reduce the economic burden. ${ }^{87}$

These difficulties discouraged disabled veterans from trying to obtain a pension. In France, about three-quarters of the invalid veterans did not demand their disability pension. On the other hand, those who did were entitled to an allocation while waiting for a decision, which allowed them to have some income, in contrast with Portuguese veterans. ${ }^{88}$ In Germany, pensions were similar to the wages of skilled workers and companies had to hire disabled veterans, like in France, and could not easily discharge them. ${ }^{89}$

While the majority of disabled veterans across the world demanded working opportunities, this was a sensitive issue, often criticised in the media, particularly during the 1930s crisis. In Great Britain, governments were reluctant to institute programs for employment; however, with the King's National Roll Scheme for Disabled ExServicemen, companies were encouraged, although not obligated, to hire disabled

\footnotetext{
${ }^{86}$ Carden-Coyne, 'Ungrateful Bodies', 551-8.

${ }^{87}$ Carden-Coyne, The Politics of Wounds, 342-50.

${ }^{88}$ Prost, 16, 26.

${ }^{89}$ Horne, 601; Cohen, 4-5.
} 
veterans. ${ }^{90}$ In France, disabled veterans were granted priority access to public positions in 1923, and in the following year, private companies in industry and commerce with over ten employees were to prioritise invalid war veterans. The number and weight of French invalid veterans' associations were significant, contributing to the creation of the Office National des Mutilés, which also existed in other countries such as Italy. Furthermore, in France, there was also a strong political representation of the gueules cassées (broken faces) with Colonel Picot as deputy and under-secretary of the State. ${ }^{91}$

Although the Portuguese state tried to legislate in favour of disabled veterans, its responses arrived rather late and were often incomplete. Governments were quite negligent towards disabled veterans, who felt extremely frustrated. As a result of the political, economic and social situation in the aftermath of the war, to which we must add the fact that the disabled veterans had no political voice, there was no national coordinated or coherent policy for rehabilitation, no specific organism to answer the demands of disabled veterans, and no established program for employment, particularly for companies. So, rather than becoming a political player, this group felt abandoned and consigned to oblivion.

This work was supported by Fundação para a Ciência e a Tecnologia (FCT) under the project IF/00631/2014/CP1221/CT0004.

\section{Notes on contributor}

\footnotetext{
90 Horne, 601; M. Kowalsky, "This Honourable Obligation": The King's National Roll Scheme for Disabled Ex-Servicemen 1915-1944, European Review of History: Revue européenne d'histoire, 14:4 (2007), 567-84, <http://dx.doi.org/10.1080/13507480701752201> [accessed 12 January 2017].

91 J.-C. Fichou, 'De l'irrationalité de la loi de 1923 sur l'emploi des mutilés de guerre dans le service des Phares et Balises', Annales de Bretagne et des Pays de l'Ouest, $121: 1$ (2014), 150, $<$ http://abpo.revues.org/2737> [accessed 27 March 2016]; P. Sofia, 'La blessure et la mutilation des combattants dans les affiches françaises de 1914-1918', Matériaux pour l'histoire de notre temps, 103 (2011), 53.
} 
Helen da Silva is currently working on the project 'Medical and Healthcare services in the First World War: the case of the Portuguese soldiers during and after the Great War (1914-1960)' at the Institute of Contemporary History (IHC-NOVA-FCSH) in Lisbon. She holds a $\mathrm{PhD}$ in History from the École des Hautes Études en Sciences Sociales (France) and by the Universidade do Minho (Portugal) with a thesis on nursing history. She has published several articles on these topics.

Correspondence: Helena da Silva, Email helenadasilva@fcsh.unl.pt

ORCID: 0000-0002-0103-4291 